\title{
The Dodo Bird
}

\author{
From the Dick Gibson Show: \\ Fabulous Battle Broadcasts of World War Two-Mauritius
}

Stanley Elkin

"Dick Gibson talking low on the low band.

"We're on Mauritius. Formerly Ile de France. Indian Ocean, east of Madagascar. Breasting the 20th parallel like a runner breaking the tape. Sister isles, all volcanic-Réunion (a French possession), Rodrigues and the St. Brandon group. (Who's St. Brandon, patron of what? Sounds English to me. How did he get those spic brothers Réunion and Rodrigues for sister isles? What miscegenous, nigger-in-the-woodpile history went on here anyway? Who, wanting something for nothing, looking for what trade routes, asking the way east from the way west like those other old junkmen of science, the alchemists, lowering what boats of which mutineers or the sea-sickened say, burying the beriberied, promising to return, putting them ashore-as the government Collins and me-on some openended will-call, found this place? Charted it on maps, informing the old cartographers so they could erase their ancient lame finesse, Hic sunt leones? It is the world, real as Paris. And ah significance returns, grazing the surfaces of the place like that random spinning spotlight of the world, the sun, illuminating-the light is terrible, I have no smoked glasses, though Collins, an officer does-the landscape as monks an initial letter in an old text.)

"There's not much here. Lieutenant Collins agrees. Wait, I have my map. Hmn. Well. Hmn. Oh. Mnh hmn. Say, let's try that. Here's how I read it. I see from the Miller Cylindrical Projection that we are the last island cluster of democracy in the Tropic of Cancer, a short-as the bomber hops-hop from the Tropic of Capricorn Border. We are the Gateway to the Antarctic then, a bright prize in the tactics, a key cog in the bitter battle to control the glaciers. Yes. The glaciers. Am I getting warm?

"When I was a boy I imagined war as a cataclysm, an extended chaos. There was nothing in what I read of the daily, and I puzzled where soldiers slept, when they ate. After a while I came to believe that wars had no silences save those of ambush. War seemed some eternal fire, sourceless and undying like a nasty miracle. Just a hint of the undisrupted was more exotic than the fiercest massacre. There's our humanity-to feast on the commonplace and make a mystery of the ordinary. What, the mail goes through? The lottery isn't stopped? The restaurants are full? Imagine. Now I perceive something of the thinness of cataclysm and know that more bombs fall in the sea than on the city, and I gauge the under- 
lying delicacy of the world. But a piece of my terror hangs on. In neutral Lisbon -we flew from Lisbon on a commercial flight to Portuguese Angola-where uniformed Germans and uniformed Americans walk side by side and buy papers at the same newsstands and ask the same questions of the hotel porter, and wait behind each other at the gas pumps, and no one draws his gun and there is less skullduggery than in Cleveland, my flesh crawled and I had bad dreams. Collins flew in first class and I in economy and sitting beside me was a Japanese soldier who helped me recline my seat because the button was stuck. Neutrality is the miracle.

"Unless Collins has secret orders-he swears he hasn't: you see, our proximity has made us neutral; already he swears to me-I don't understand what's happening here, or why we came. There's nothing to report. There's the garrison of British soldiers, here since before the war. (Mauritius belongs to the British.) These men, never rotated or reinforced, seem residents of the place, as much its citizens as the Chinese, Dutch, Indians, French, and Africans-called Creoleswho live here. Occasionally there are reports that the Japanese have put troups ashore on one of the nearby islands and then there is a flurry of activity as the men go out on patrol. There's some evidence that there are Japanese around, a few, but at no greater than patrol strength, and as they make no move to threaten the garrison at Port Lewis, the island's principal city, the British don't try to engage them.

"It's pretty much a planter culture, no industry and a rattan feel to the texture of life. I guess at its essences. Mauritius would use its barks and leaves and boles. Commerce blooms from its rangy stalks and thorny brush. There are goods in its grasses. I smell high grade hemps and queer cocoas. I sniff deck tars, caulking syrups, and narcotics in its fibers-hashish and bhang and cannabin. And there is something brackish and briny in the tangled mat of the growth, as though the vegetation were merely the dried top of the sea.

"Collins and I, per our orders, protect the equipment. One of us is at the transmitter at all times. Off duty I either drink with the British or roam about the island, perhaps climb the grassy slopes of the volcanos that acne the landscape. I've exhausted Port Lewis, seen its single museum-a curious place which in addition to its limited collection of paintings, mostly by the planters themselves, holds the world's largest collection of the skeletons and reconstructed corpora of the extinct dodo bird which, for some curious reason, once thrived on Mauritius and Réunion isles.

"Is this the sort of thing you want?"

"A tip of the Dick Gibson cap to the High Command. You knew what you were doing all right. Increased activities among the Japanese. A few small landing parties spotted by some of the planters. They disappear quickly into the jungle. No real alarm at the British garrison at present as there is no evidence that they are bringing any heavy equipment with them."

"Still more landings reported. They seem to be concentrated on Réunion, though one or two have been seen on the beaches of Mauritius itself. Yesterday 
a cache of armament, though of a strange sort. Primitive. Perhaps for jungle warfare. The British Colonel here says the stuff looks almost like traps. One interesting sidelight-some of the Japanese accompanying the soldiers are dressed in civilian clothes."

"A Japanese task force has been spotted steaming towards Mauritius, about two days off. The garrison has been placed on alert. All Asians are under strict scrutiny. The build-up on both sides is terrific now."

"Perhaps as many Japanese as British about, though both forces have thus far managed to stay out of each other's way."

"The Royal Air Force is here."

"It's a collision course all right. Though still no major engagements yet. One of the Japanese civilians attached to the Jap Army was captured and interrogated. He turns out to be a scientist-an ornithologist."

\section{“The report has come back. It's official. HIC SUNT DODOS!"}

"The dodo is an extinct species of ungainly, flightless bird of the genus Raphus (or Didus). Its incubation ground and later its world was the island of Mauritius. It was closely related in habit and aspect to a smaller bird, the solitaire, also extinct but once indigenous to the island of Réunion (which, perhaps by coincidence, is closely approximate in shape and size to the island of Mauritius). It has been long held by ornithologists that the dodo-both the dodo proper and the solitaire will be henceforward subsumed under the pseudo-generic term 'dodo'-was related to the pigeon, but this is only an hypothesis since the bird has not been available for study since 1680, the year that the last known dodo died. (Although this curious bird, the better known Mauritius dodo, was sent to European museums, no complete specimen exists, and today only a foot and leg of a dodo are preserved at Oxford. The representations one sees, even in the Mauritius Museum of Art itself, are merely restorations, little more than cunning dolls constructed on the skeletal frames of dodos.) Nevertheless, the skeletons, the scattered bones of which are to be found abundantly even today in the Mauritian fens and swamps, painstakingly reassembled by Mauritian dodo artisansthe best in the world-give an accurate picture of what the bird was like.

"He was a large bird, slightly bigger than the American turkey whom he in no mean way resembles. In silhouette the dodo is not unlike a great scrunched question mark. For detail we may refer to the many paintings from life that have been made of the bird. In this respect we are extremely fortunate for since Mauritius was populated in the seventeenth century largely by the Dutch, and since this was the age not only of the dodo but of the famous, highly realistic 'Dutch School' of art-Rembrandt is a good example-a school of painting noted for its assiduous attention to the rendering of perspective and detail, we may depend 
upon the accuracy of the dozens of sketches and oil representations of the dodo bird, many of the best of which are still here in the Mauritius Museum of Art and Dodo Reconstruction. Most of the dodo artists seem to be in agreement that the animal was possessed of an enormous blackish bill which, together with the huge horny hook in which it terminates, constituted the shepherd's crook of the question mark. Its cheeks, partially bare, seem oddly weather beaten and muscular, almost human in fact and not at all unlike the toothless cheeks of old men who have worked out in the open all their lives. Black except for some whitish plumage on his breast and tail and some yellowish white vaguely the tint of old piano keys on his tail, he was somewhat formal in appearance, if a trifle stupid looking. This formal aspect of the dodo is attributable also to his wing, foreshortened as a birth defect, which, in repose, flops out and down from his body like an unstarched pocket handkerchief.

"Dodos are said to have inhabited the Mauritian forests-this is the style of information, of certain kinds of fact; I find it relaxing-and to have laid a single large white egg which they mounted high in a setting of piled grass. Hogs, brought in by the settlers, fed on the dodo eggs and on the dodo young and, in one or two dodo generations the birds were extinct. Ah Malthus, geometer, you knew.

"By now you have the reports, the action paced off in the war room, set pin for pin like surveyor's stakes in alignment, the lines drawn in a terrible cat's cradle of possibility. This, what $I \mathrm{do}$, is something else.

"The build-up was flawless. Men came from the sea, from the air. They peeled off the landing craft and ran up the beach like barbarians. Paratroopers bloomed in the sky like flowers and grew into the ground. No more Lisbon to Portuguese Angola to Mauritius night coach fumblings. The trade routes are really open. I celebrate the Department of Deployment, reinforcements, fresh troops. (There's something virginal in the sound: showered, shaved, their fight untapped, blossoming in their bones and pink skins. 'Fresh troops.' It sounds pasteurized.) And cooks to feed them and clerks to count them. And the Japs the same. As good as you in producing populations out of thin air. Moses, a piker, hadn't near so many, and it took him a forty-year hike over rough road and if the troops ate well it was because of a miracle. You do better.

"But you know. And who am I, Dick Gibson, to be telling you High Commanders on High all this? I'll tell you what happened. History is good experience for me, the itinerant radio man.

"Collins is the officer and must command me to rise. Yesterday he came to my room to wake me but this time I was already up. I'd awakened before dawn. I'd heard some noises and couldn't fall back to sleep. At first I thought the engagement had begun, but when I went to the window I could see no fire flashes -just some trucks and black shapes moving in the street. I assumed that more reinforcements were going toward the garrison. Then it occurred to me that they might be Japanese and I called down in English. A British voice yelled up at me and I got back in bed.

"Then something which has always been undeveloped in me-I mean my sense of place-suddenly surged up and was almost overpowering. Why here I 
am, I thought, on Mauritius, one of three or four places on the globe which merely to have seen qualifies a man as a traveler, I mean a wanderer, one of those whose fate it is to be troubled by laundry, by mail with old news, irregular bowel movements, a certain ignorance about time and a taste gone crochety through nostalgia for things eaten long before. I have no languages and carry no flags for Isabel. How did I get this way I wondered. It is no accident that one finds himself sizing smooth pebbles on the cold coasts of Tierra del Fuego. To see a desert is to scorn a city, and to lick a finger that has once been in the Weddell Sea is to eschew the ordinary salts forever. What had earned me distance? In America I had criss-crossed the country, leaping in and out of landscape, doing a journey of wild, erratic stitching. The mile is a measure of madness, too, and a map is hot pursuit. (This is still the war news.) Gradually the room grew light and I could perceive the objects in it-the four-bladed fan that hung from the ceiling like a great spider, the cane furniture like petrified vegetable, the huge wardrobe, big as piano crating, the white mystery of the mosquito netting. They were the solid evidences of my own strangeness. Why am $I$ far afield?

"I rang for my tea and pork chop-think of that, a pork chop for breakfastand the little half naked Creole brought it up on a tray. Still standing beside my bed he kneaded the warm half-baked dough they use here as rolls and pinched the last counter-clockwise swirls into it. (How does he live? He is fourteen and already married and a father as well. My $15 \%$ service which must be divided with the chambermaids and hall porters and laundry people and maintenance men cannot keep them all. This hotel has been practically empty since the war began. What strange arrangement goes on here?)

"As I was finishing my breakfast Collins came for me and we went to the garrison. It was deserted. The troops I'd seen were not reinforcements. They'd been pulling out.

"'Where could they have gone?' Collins said.

"I stood with all my weight on one hip, the open, deferential stance of one waiting for someone else to make a decision for him.

"'Something may be up,' Collins said. 'We ought to find out where they've gone. There's probably someone around.' We found a man in the infirmary. He told us the garrison had left to make contact with the Japanese at the southeastern edge of the island, about a half day's trip over rough terrain.

" 'Looks like the real thing,' Collins said. He did not seem very happy. 'What the hell is all this about anyway, Dick? How'd a couple of old radio men like us get involved in all this?'

"In a way he was thinking the same thoughts I had earlier, but I only shrugged.

"You believe all that shit about the dodo bird?' I didn't answer. 'Bird extinct two hundred and fifty years suddenly shows up. Damned island extinct about the same time and all of a sudden it's a major theater of operations. It must have something to do with that bird. That's what the talk is, but no one knows. What do you make of it?'

“'I don't know, Lieutenant.'

“' 'You said they've got some stuffed dodos at the museum.'

“'Representations, cunning dolls.' 
" 'Let's go over and look at them, see what all the fuss is about.

"We went to the museum. Collins treated.

"I knew the collection pretty well by now and I started to take him through. He wasn't really paying attention, and barely glanced at the glass cases. 'We could still be in London, you know that? You had to go haywire.'

“' 'No excuse, sir.'

" 'No, hell, water under the bridge. Boy, it sure spooked me to see you were so highly connected. What did you have on that general anyway?'

"'I once took a burr out of his paw.'

"'Yeah. Ha ha. You know something? I don't think this war can last much longer. You going back into radio when it's over?’

"'Yes, sir.'

" 'Not me.'

" 'No sir?'

“'Television.'

" 'Oh.'

“' 'That's where the money will be. Radio's had it.'

“'I'll stick to radio.'

“'Will you?'

“'Yes sir.'

“' 'Well it's all a matter of what you're comfortable doing, I guess.'

“' 'It's been pretty good to me,' I said.

"Soldiers had been talking this way for hundreds of years in the respites before big battles. I don't think he saw me but I began to cry. A chill went through me. Something about our voices, the sound of our dropped-guard friendship, told me that something terrible was going to happen. As he spoke hopefully and confidently about the future, I expected Collins to die, to be hit by a grenade, his head torn off. I thought that it would not be long before I would see him dead at my feet, his neck broken. I wanted to tell him to hush but of course I couldn't.

"Then something odd did happen. We were in the picture gallery. (All about us were the dark oils of the early settlers-pictures of dodo hunts, the excited Dutchmen ruddy and breathless from the chase, the dodo cornered, maddened perhaps by its ordeal, something like hatred adjusting itself to the stupidity of its gaze; other paintings, several still-lifes of Mauritian feasts, tables spread with the island's fruits, halved cuchacha melons white as moonlight, tangled wreaths of the gnarled fruit vines that trellis the cones of the volcanos, the dodo birds prepared for cooking, split, the guts, like long, partially inflated balloons, tossed into a slopbucket, their long necks limp, the beaks open in death and their bare, old men's cheeks flecked with blood.) I had thought that we were alone, but suddenly I heard a low bark of heartbreak, of grief. We both turned. It was the captured Japanese civilian. He was sitting on one of those benches that they put in the middle of picture galleries for meditative purposes. Probably he did not see us. There was a strange rapt expression on his face, and he was weeping.

" 'How did he get loose?' the lieutenant whispered. I shook my head. Collins drew his service revolver-since that time in Broadcasting House when he'd placed me under arrest he always wore one-and pointed it at the man. 'Hands up, he commanded. The scientists appeared not to have heard him and Collins 
went the rest of the way up to him. 'I said hands up.' Still the fellow did not acknowledge us. 'Hands up and stop crying.' At last the Japanese turned to Collins. He seemed very tired. Wearily he raised his arms.

"'What are you doing here?' Collins demanded. The Japanese just stared at him. He looked like someone in touch with something really important suddenly forced to deal with the ordinary. I didn't know what was on his mind but I was glad $I$ wasn't the lieutenant and that $I$ didn't have to ask the questions. 'Come on, fellow. You don't have to speak our language to get our meaning.' He waved the pistol at him. He shook it in his face. 'Move out smartly. I said move!' The man merely looked away from Collins again and stared across the room at a large painting of a dodo bird in the forest. He rubbed his eyes. 'And you can cut out that sniffling,' Collins said gently. 'We're not barbarians. We're American soldiers and you're a prisoner of war, subject to rights granted you under the Geneva conventions. You're our first prisoner and we aren't exactly sure of what those rights include. We'll have to look them up, but meanwhile we're not going to hurt you. You have to come along with us though.'

" 'I am not afraid,' the Japanese said calmly. 'And I will go with you. But first, can you please give me one moment alone in here? As you can see, this is the last gallery. If you stood by that archway there you could observe me. Obviously, I have no means of escape.'

"I must confess something. I was very excited at the prospect of taking a prisoner. I felt something like an instinct move in me. 'Don't do it, Lieutenant, it's a trick,' I said.

"The man looked at me contemptuously. I had remembered something I knew would be true about my life-that I would have melodramatic dealings. Although I regretted what I'd told Collins about its being a trick, it had seemed the only thing an enlisted man could have said.

“'Please, Lieutenant,' the Japanese said, 'you can see that there is absolutely no way out for me.' He patted his pockets and opened his palms. 'I am unarmed.'

“'How come you talk such good English?' I said threateningly. He seemed disappointed in me. I didn't blame him. I felt my sergeant's stripes sear themselves into my arm.

“' I am a scientist,' he explained coolly and looking at the lieutenant. 'English is the official language of ornithology.'

“ 'Hmph,' I said.

“'Please, Lieutenant, I will go with you now. My meditations'-he looked at me-'are over.'

"He rose, his eyes downcast, his body just visibly stiffening as we went by each of the paintings. In the gallery with the environments in which the dodo birds were displayed he would not look up, and once, his hand accidentally brushing against one of the glass cases, he jumped back as if stung. 'Pretty odd behavior for a so-called scientist, wouldn't you say, Lieutenant?' I whispered in Collins's ear, regretting my style even as I spoke. My stripes lashed me. They drove me to feats of clown and squire. It was all I could do to keep from ripping them off. 
"Once outside the museum the Japanese seemed more comfortable. We took him in a taxi back to the garrison and let ourselves into the guardhouse.

" 'How did you escape?' the lieutenant asked our prisoner.

“' 'I didn't. I was abandoned. They forgot about me.'

"'What were you doing at the museum?"

" 'I'm an ornithologist.'

"'You're the one who discovered the dodo.'

" "No. I identified him.'

"I went over to Collins. I was still smarting from all the things I'd said up to now. 'Listen, Lieutenant,' I said, 'I think there's more going on here than we appreciate yet. Give me a few minutes alone with him.'

" 'Why? What good would that do?'

" 'I think I know some ways of getting him to talk.'

“'He's a prisoner of war, Sergeant.'

"'Yes sir, but our buddies are out there. I think this gook knows more than he lets on.' The scientist rolled his eyes.

" 'Many hundreds of years ago-' he said.

“' 'Talk, I hissed.

"Many hundreds of years ago, during the dynasty of the Emperor Shobuta-' the man said.

“' 'That's it,' I said lamely, 'keep talking.'

" "-there suddenly appeared in Japan, on the island of Shikoku-your Indian word "Chicago" derives from this-a single specimen of the genus Raphidae Didus, what you call dodos. How it got there is unknown, for Japan-this was the thirteenth century, three centuries before the discovery of Mauritius-was an insular nation. She had no dealings with the rest of the world. The bird was flightless. Ceramics from the era show that its wing development was even less than the Mauritian representations. Naturally the bird was a curiosity. The curator of the Shikoku Zoo-we are not barbarians either, Lieutenant; Shikoku had a zoo long before one was ever dreamed of in Europe-did not know how to classify it, and was more inclined to put it with the animals than with the birds.

"Now at this time Japan was plagued by warlords. One in particular, Zamue, a Shikokuan, was a threat to the Emperor himself, a man of mild manners and ways whose paths were peace. Zamue, in contrast, was a fierce Samurai who had in the course of events left a trail of bloody victories from the island of Yezo in the north to Kyushu in the south.

"Now it came to pass-you have this idiom?-it came to pass that a court counselor, one Ryusho Mali, recognized the need to instill courage in our Emperor, and when he heard about the strange wingless bird that had alighted in Shikoku he sent for it in order to examine it for its qualities as an omen. He had expected something like a peacock, perhaps, or a cassowary-both rare in Japan but not unheard of-or even a parrot, but when he saw the animal-I use the curator's term-he was extremely disappointed. How could so foolish looking a bird bode well for the state? Nevertheless, setting aside his prejudices, he proceeded to examine it closely. Perhaps it enjoyed some of the properties of the parrot and could be made to mimic human speech. Ryusho Mali recalled how a predecessor of his had once done something notable for his country through an 
ordinary crow. Ryusho closeted himself with the bird and examined it. He tried to train it to say "Courage," thinking that perhaps the hard " $k$ " sound might be natural to it, but, alas, he quickly discovered that the bird had no voice at all. It was mute as a turtle. He wondered if something cheering might not be done with the feathers, but there was little inspiration or hope to be had from that quarter because of the lusterless black and dingy yellow with which the bird was covered. Ryusho Mali was disconsolate and put the bird away from him, commanding that it be sent back to the zoo in Shikoku to be stared at by the multitudes for the pointless novelty it was.

" 'The Emperor Shobuta-whose very name means compassion-was himself an animal fancier, no hunter but a lover of beasts. (Perhaps he saw that they had qualities which he himself lacked. It is often the way. We have an expression: "The grass is always greener on the other side of the fence." At any rate it is well known that fish and birds are the most fascinating animals to man for that the one can live in the sea and the other in the air.) It was Shobuta who had decreed that there be a 200-for the 200 distinct animal types; the " $\mathrm{z}$ " in the word "zoo" is a corruption of the " 2 "-and every day he would visit there, consoling himself with the mysteries of creation.

" No sooner was the bird returned to its pen in the 200-as I've said, the curator did not know how to classify it and ordered that it should be put in with the hogs-'

“'But hogs-' I said.

" 'Yes,' the ornithologist said. 'Exactly. No sooner was the bird returned to the 200 than the Emperor, who had been away at his summer palace when the bird was first discovered, saw the bird and was furious-as much as it was possible within the terms of his sweet nature for him to be furious-that it had been put in with the animals. He had recognized it immediately for what it was. Oh, I don't mean he knew that it was raphidae didus, but he saw that it was a bird. He was, as I say, furious. His exact words were: "What iniquity is this? To break off the wings of a bird"-for that is what he thought had happened-"merely to indulge the crowd's appetite for the grotesque! I will not have this! A nation which stoops to the barbarity of a Zamue the samurai does not deserve to be sustained. What, are not wings marvelous enough? We have an expression in Japan-to gild the lily. It is to situations like this that such an expression applies."

"It was the first time anyone had ever seen the Emperor so angry, and though it was explained to him that no one had tampered with the bird, he would not believe the demurrers. He ordered the bird released and brought it back with him to the palace. There he annointed the nub of its wings with precious balms and unguents. I said before that man admires and loves those qualities which he does not himself possess, but he loves also to recognize in the other those which he does. Both things are true. Perhaps the Emperor's heart had responded to something like his own winglessness in the bird's. At any rate it is known that he cherished the bird as he had cherished nothing before it, and that he kept it with him always.

" Now something must be said of the warrior Zamue. Remarkable as it may 
seem for one so successful, he had no followers. He permitted himself none. The fact is he was not so much warlord, or even Samurai, as he was assassin. He was a man of a thousand disguises and wreaked his havoc through the art of murder-which he had perfected. He had murdered men by drowning them and murdered them with poisons. He'd done murders with knives and murders with clubs. He murdered them awake and he murdered them asleep, and he murdered the sick as well as the well. He had great strength and murdered them by lifting heavy objects and then letting them fall on the tops of their heads. He shoved men off cliffs and lured them from the sea to the rocks with false signal lights. He murdered by loosing beasts and by cruel degrees of torture. He pushed them against walls and squeezed them to death. He murdered with gunpowder and murdered with strangling, by forcing sand up their noses and holding their mouths. He murdered them by repeatedly kicking them hard.

" 'He preempted whole kingdoms by killing the leaders, and had worked his wicked way up the chain of proprietorship till all that stood between himself and the sandal-we say "sandal" and not "crown" in Japan-was the life of Shobuta the Tender. Him he had saved for last as one reserves the sweetest morsel of a feast.

" 'Shobuta knew Zamue was coming. He doubled his guards, tripled them, but in his heart of hearts he had no faith that this would keep off the assassin's depredations. Zamue, as has been said, was a master of disguise. The chances were excellent-better than excellent-that one of his own men was Zamue. He reasoned that by increasing their number he correspondingly increased the chances of Zamue's being amongst them. He reduced the guard by a third, by a half, by three quarters. In the end he relieved all but his most trusted attendant and made him his entire guard. (I know what you're thinking.)

" 'Zamue was a fatality, a fate-in our country we have a saying: "What will be will be"-and all that the Emperor could do in these last days was care for the bird, minister to its winglessness. "I will be your wings," Shobuta whispered to it, and carried the dodo everywhere. "Surely you are not so high as once you soared," he would tell it, and then add, thinking perhaps of his own circumstances, "We all come down."

" "In this wise the Emperor continued for weeks, for months. Each night as he lay his head on his pillow he could not but question if he should ever see the morning.

"'It is well known that birds tuck their heads under their wings when they sleep, but what of wingless birds? Shobuta took the poor dodo to his bed with him. "I told you I would be your wings," he reminded it softly, and touching his right hand to his right shoulder, Shobuta the Tender raised his elbow. The bird, with an uncanny instinct, nuzzled up to Shobuta's armpit, and the Emperor put the "V" of his doubled arm gently down over the dodo's head. In this wise they remained all night.

" The great feast days approached and Shobuta thought that Zamue was soon to make his move. (In our country, as in most, there is the old saying: "Strike before the feast days if you would have victory.") Each day now he peered outside the door of the imperial apartments and glared accusingly into 
the face of his most trusted lieutenant. (Should not what has occurred to you occur also to the greatest scholar of his time?) He never remained long, but every afternoon at exactly the same time Shobuta would step out and, gauging it perfectly, waiting until the circle of his tour brought the man before the doors to the imperial apartments, he would, at the precise moment when the eyes of the "trusted lieutenant" met his own, whisper softly "When, 'Lieutenant?' How?" In my country we have the expression "battle of nerves." That's what this was. The man never answered of course, for that is against the basic rule of guard duty, but a small ambivalent is always permitted, and sometimes he would proffer one of these to the Emperor. Sometimes not.'

" 'Why didn't the Emperor-?"

" 'Discharge the lieutenant? Zamue was a master of disguise, Sergeant, a master. With his great strength and fabulous muscle control he could alter his size and the actual features of his face. If only he had used his powers for good - But-

" "The feast days came and the feast days went and still Zamue had not put in his appearance. "So," the Emperor thought, "he did not abide by the venerable saying. How clever the fellow is! How clever and how wicked!" Yet troubled as he was-Oh. I forgot to mention something. The Emperor had little feeling for his personal safety, but very delicate negotiations were going on in Japan at this time, negotiations which the Emperor himself was behind and that required his leadership if they were to succeed. Also, he was disturbed by what would happen to the dodo when he was no longer there to care for it. As I started to say, troubled as Shobuta was, he never let on to the dodo bird that anything more serious than the dodo's winglessness concerned him. No. With the dodo he was always careful to seem gay. He took up singing and sang for the voiceless bird with apparently unflagging spirits. If the dodo appeared to tire of a particular song Shobuta the Tender immediately removed it from his repertoire and learned two new ones for the one he had discarded. He noted which songs appeared to give the dodo especial pleasure and had the court musicians compose new ones along the lines of these. Only during that brief moment during the day when he went outside to confront his lieutenant did his anxiety surface and this, thank God, was a moment the bird was not permitted to share.

" Things continued in this wise till the next feast days and still nothing happened. Then, one day when he had just completed a new song that the dodo had never heard before, Shobuta began walking to the hallway at the other end of which stood the huge double-thick ivory entrance doors to the imperial apartments, first, of course, setting down the bird and making his customary admonition that the dodo was not to follow.

" "The Emperor went down the long hallway, his tender anger building as he thought of the duplicities and treasons of him who had so long kept him waiting for what he still thought of as his fatality. Only the knowledge that he had recently completed the delicate negotiations which he had feared would be prematurely cut off when Zamue struck, softened his heart toward his malefactor. By the time he arrived at the enormous doors it was all this tender, gentle man could do to fix his features in a scowl. Though he was now quite empty of hostility, he felt he owed it to his enemy to present a face that showed resistance 
-since he knew, you see, that the cruelty of a Zamue thrived on such things and the tender Shobuta did not have it in him to disappoint even Zamue.

" "What was his surprise then when he opened the door and saw his "trusted lieutenant" laying dead at his feet, his neck broken and his chest struck quite through with a sword! His first words were typically Shobutian. "Hurrah!" he exclaimed, "The bird was spared seeing this!" Then he began to grieve that his "lieutenant" had come to such a dreadful end. He kneeled down over the man's prostrate body, and his eyes misted over with tears. Only when they had at last cleared did he see that he was not alone there. He found himself staring at a pair of the largest feet he had ever seen. Horned they were, and scaly. He looked at the greyish shins, hard as broadswords, and up the cutting edge of the thighs, and all the way up the rest of the long, thick body until he was staring directly into the face of-the warrior Zamue, the assassin Zamue!

"“ "But-"the Emperor said.

“ “ "It is I. I come undisguised."

" "It was the real face of Zamue, the powerful muscles relaxed for once, collapsed in the fierce pile that was his natural aspect. It could be no one else. Aiiiee, the Emperor thought, he means to kill me with his ugliness. I must not look.

" 'Zamue reached down and pulled the Emperor to his feet, and was just about to kill him by biting his jugular when suddenly he released him and began to laugh uncontrollably.

"“ "Ho haw hoo hoo haw ho ha!" laughed the assassin, pointing to something behind the Emperor's back. Shobuta had forgotten to close the door behind him, and when he turned he saw that what Zamue had been laughing at was the wingless, ungainly dodo waddling down the corridor toward them. Shobuta-he did not want the bird to see what Zamue was about to do to him-immediately made to close the doors, but Zamue restrained him. "No, let him come," he roared. "I have never seen anything so ridiculous. Look. He has no wings. A bird with no ho haw hoo hoo wings!" The bird continued to come toward them, his waddle more graceless than ever. In his haste to be reunited with his friend he appeared to stumble, to fall, to pitch, to buckle. At one point the bird actually seemed to drop to one knee. Zamue thought he had never seen anything so comical than this fat bird, bigger than a turkey, with his glazed, bulging eyes that made him seem so stupid. "Hoo haw haw hoo. Just look at that booby, will you? If you want to know I think it's drunk."

" "Then, just when the bird had reached our Emperor and was nuzzling against his knees, Zamue recovered himself. He drew the sword from where it was sheathed in the lieutenant's chest, and raised it high above his head.

" " "Say your farewells to your clumsy friend, Shobuta, for now I am going to split you in two," Zamue shouted. Saying this, and seeking additional leverage, he raised himself up on the powerful balls of his enormous feet and made to chop with his sword on the Emperor's crown-we say "crown" when we are referring to the head-when suddenly the bird appeared to drift up into the air. The wingless bird had flown! Not flown, not flying, but floated, floating-rising -risen!

" 'Zamue's eyes widened in horror. "Yeeeeeghch," he screamed, and still 
stretching for leverage with the sword above his head, his fright and his imbalance and the weight of his weapon toppled him backwards. Shobuta, moving quickly and almost without thinking, recovered the sword and plunged it into the assassin's heart. The giant writhed and thrashed. His throes were terrible, but it was all up with him. In minutes he was dead. Interestingly enough-so evil are some men-he had actually lied to Shobuta just before he had been about to kill him. He said he had come undisguised, but his features changed still another time, and as death relaxed them his muscles flowed like currents to build a final tidal wave of horror beneath his skin. Only now was he undisguised.

" 'In the excitement Shobuta had lost track of the bird. Now he looked about for it, and found it some yards away, on the ground, squatting in a corner. It seemed clumsy as ever, stupid as ever. It had flown but one moment-in the instant of its dear friend's need-and now it was as it had been before.'

" 'That's quite a story,' Collins said after awhile.

" 'It isn't finished,' the Japanese said.

“'Keep talking,' I said.

" 'The news of Zamue's end spread throughout the empire, and all at once, in the vacuum created by the death of the assassin, many vicious men began to struggle for power. This was a terrible disappointment for Shobuta and for all those others in the empire whose paths were peace. But-the Japanese have an expression: "First one thing, and then another." Terrible as it must have been for him, Shobuta knew that he could no longer sit idly by while the empire was being torn to shreds by contending forces. He was a changed man. From Shobuta the Tender he became Shobuta the Jealous. Wherever there was insurrection, there, too, was Shobuta. He met each challenge forthrightly and with all the force at his command. And this force was now considerable. Reports of the bird's miraculous flight had traveled the length and breadth of the empire, and bit by bit the strange powers of the bird to fly were transferred to and identified with the Emperor. Shobuta had become irresistible, rosichicho-invincible. His enemies, and there were many, fell back before him as grain before the wind. Before long almost every pocket of resistance had either been defeated or dissolved of its own accord. Only one man, the shogun Korogachi, the most powerful of all Shobuta's enemies, had still to be encountered. A wily warrior, he pretended to encourage a belief among the people in the Emperor's new powers. In this way he thought to let the Emperor do his work for him, and to inherit a docile Japan once he and the Emperor-you say "locked assholes?"

" 'Only when there were no more seditionists-save himself-did he declare that he disbelieved the Emperor's story about the wingless bird. He let it be known that he thought the bird was a hoax, a desperate fabrication of the Emperor's counselors-he presented proof, for example, that the bird had been with the cunning Ryusho Mali long before the Emperor had ever laid eyes on it-and that when he and Shobuta met on the field of combat, man-to-man, no crippled-ha ha-bird would have any bearing on the outcome. He put it out that the real miracle was the so-called "character change" of the Emperor, and declared that he had no more faith in Shobuta the Jealous than he had had in Shobuta the Tender. "If you want my honest opinion," Korogachi liked to say, "the man should be known as Shobuta the Showboat!" 
" "When Shobuta the Jealous heard what the shogun had been saying about him he was furious, and insisted on setting out at once for their confrontation. He demanded that the bird be brought to him from the temple where it had been kept for safekeeping and religious observance ever since the day of its fabulous flight. "We shall just take the wondrous bird with us this time since Mister Korogachi proclaims not to believe in its powers! Perhaps it will show again what it can do. Who knows but what it may fly in his face and peck out Mister Korogachi's eyes?”

" 'In this wise, feeling himself invincible, and now singing martial airs to it where before he had sung lullabys and poems and love songs, Shobuta set off with his army, the bird waddling along beside him.

" 'I shall not dwell much longer on this history. Shobuta's forces were met by an enormous army. The holocaust raged for three days and three nights. The noise of battle was fantastic. The clank of armor was added to now not only by the screams of the dying but by the bangs and booms of the gunpowder, which had only recently been invented. The sound was simply terrific.

" "There is, as you know, everywhere in nature a law of compensation. When a leg is injured or lost an arm grows stronger. Often a man with no arms can paint the most amazing pictures with the brush between his toes. He who has not the sense of sight is frequently preternaturally blessed with the sense of touch or smell. In the bird world it is the same. For some reason, winglessness may be compensated for by a particular acuity of hearing. Historians speculate that Shobuta the Tender had a lovely voice-one particularly well suited to accommodate the soft nuances of the gentle love song. We scientists think it may have been particularly well adapted to mesh with the sensitive hearing of the miraculous bird. The martial, fervent stridencies of patriotic petition were something else. So, too, were the harsh noises of that awful battle. They were more than the sensitive auditory threshhold of the bird could accommodate. It went mad. There is no other word for it. It dashed its poor head to pieces on the shield of a just-fallen soldier. Perhaps, in its confusion, it identified the shield with the noise of the battle, and it sought to stop the sound by breaking its own ears upon the shield. Or perhaps both the historians and the scientists are wrong. Perhaps we have all along paid too much attention to its winglessness and not enough to its voicelessness. Perhaps voicelessness is a choice-the choice of silence. Perhaps winglessness is one. Perhaps there are birds who reject the air and choose the earth. Perhaps even extinction is a choice of sorts.

" 'When Shobuta the Tender saw what had happened, his poor heart cracked and tumbled. He suddenly remembered the gentle days when he had been closeted with the lovely bird in his apartments. He lay down his sword and gathered the bird up in his arms. "Come," he whispered, his voice broken on his emotions, "I shall once more be your wings." He began then to croon the bird's favorite song. No longer conscious of where he was, he drifted through the field of death among the fallen bodies of his foes and followers. It was such a touching sight that Korogachi, seeing it, began himself to weep. Distracted, blinded by his tears, and following now only the sound of the Emperor's voice, he did not notice one of the Emperor's warriors creeping up behind him. It was Earaki, a deaf Samurai who, since he had not heard the sound of battle, had not now 
heard that it had ceased. Seizing the opportunity of what he at the moment saw as only the momentary lapse of the shogun Korogachi, he struck from behind and felled the shogun for his Emperor.

"'Once again the bird had saved Japan.'

"The scientist finished. It was a while before either Collins or I could speak.

“' 'You're here for the bird,' I said.

“'We are losing the war. Only a miracle-' His voice trailed off.

"I nodded. His story had unsergeanted me, pulled the chevrons (like so many staples in my flesh) from my arms. We'd been through it. If ever we met afterwards-I looked from the scientist to the lieutenant. Collins' eyes shone. 'He knows where it is,' he said suddenly.

" 'Sir?' I said. I was fearful. I knew enough to be fearful.

“'He knows where it is. Don't you see? They've already got it. Or maybe they haven't but they're close to getting it. At any rate it's still on the island. That's why he told us. So we can get word to the troops not to shoot. Can you think what it would mean if we could capture that bird?' The Japanese smiled. 'You see?' Collins said, pointing at him and talking fast. 'He wants us to try. They haven't got it. They haven't got it because he's the expert, and he know its ways and its lairs. The bastard is challenging us to try. He's teasing us to try. That's what he was doing in the museum-studying it. Then he was going after it, but that's when we showed up. Right? Am I right, you?'

" 'All correct,' the scientist said. He was still smiling.

“'All correct,' Collins laughed. 'You bet all correct. He couldn't tell the British because there were too many of them, but there are only two of us. So he wants us to try. We bring him along so he can find it for us, then they grab it back. That's it, that's what it's all about."

" "But that would only make sense if there were a million Japs around to guarantee that he could get it back,' I said.

“ 'All correct, Sergeant,' Collins said.

“' 'Well then,' I said, 'it's a trap.'

“'A beauty,' Collins said. He turned to the Japanese. 'We can find a Jeep. How long till we get to the area?'

“'About nine hours,' he said. 'I'm judging by the time it took the patrol to bring me here after I was captured.'

"Collins had risen, and was moving toward the door. The Japanese was right behind him. 'But there will be all those Japs!' I said.

"Collins turned to me. 'They can't shoot. We'll stay out of their way. You'll see. Even if they get the dodo first they still can't shoot. He won't let them. That's our chance, you see.'

"Collins got on the radio and told the story to the British. He asked them to hold their fire, to give us twenty-four hours to try to get the dodo. He wanted Sansoni-that was the scientist's name-to give him the position where we'd be so he could tell the British. He refused. Collins drew his gun. The Japanese grinned. 'It's better, Lieutenant that they don't know,' he said. 'They'd be drawn to the area. Something could go wrong.' Collins nodded, and put the gun back. I had been cast adrift among brave men. It is always the case with squires.

"We found a Jeep. Though I am not a good driver, Collins had me drive and 
Sansoni told me where to go. To avoid the British we stayed off the main roads, and after awhile we had left the secondary roads as well and were cutting across plantations and through fields. We had left Port Lewis in the afternoon, and it was already dark, about ten thirty or eleven o'clock, before we saw our first Japanese. They were under orders to do no shooting, of course, but they signaled us to stop. Collins drew his gun again and pointed it at Sansoni's head. The soldiers recognized the scientist, and he spoke to them calmly in Japanese and the soldiers giggled. 'I've explained the situation to them' he told us. 'They're to inform the others on the walkie-talkie-that is an interesting English orientalization, "walkie-talkie," don't you think?-that we're coming. We won't be interfered with.'

" 'Excellent,' Collins said.

“ 'Bully,' I said. 'Why were they giggling?'

“'Oh well,' Sansoni said patiently, 'they expect that you two stand to lose our little contest.'

"It was fantastic. Every few minutes now we passed great clusters of Japanese troops. When our headlights picked them up they would simply turn and smile and wave us on. We were in a forest now, squeezing the Jeep between the trees. Here and there we could see soldiers crawling along on their hands and knees. Collins was very excited. 'It's true,' he said hoarsely, 'they haven't found it yet.' Now it was almost impossible to drive. The crawling soldiers took up so much of the space between the trees that there was no longer any roadway. I honked the horn.

“'Don't do that again,' Sansoni said fiercely. 'We're almost there. Do you want to madden it? Lieutenant, please do something about this man of yours.'

“'He's right, Sergeant. Calm down.'

“' 'Further,' Sansoni said, 'just a little further.' We drove another half mile or so. 'Now,' Sansoni said.

“'Lieutenant?'

“'Do what he says, Sergeant. Stop here.'

"The three of us got out of the car. We had passed up the Japanese soldiers and were alone in the forest. We walked through the woods for a bit and came out in a bowl-shaped clearing, perhaps two hundred feet across. Though it was very dark-there was no moon-and I'd never seen the place before, there was something familiar about it. Then I realized that it was the landscape of many of the pictures in the museum. The lieutenant was having the same thoughts. 'The glass case,' he said. 'The environment they built for the reconstructed dodo. That was like this place.'

"'Shh,' Sansoni said. 'Now it is necessary that we do not talk.'

"The grass was strange, leathery, and there was a fierce smell to the ground, as there had been to the trees we had just passed. It was an odor neither ripe nor rotten, life nor death. It was as if we smelled the molecules themselves, things outside time and form. I turned to see if there were any Japanese behind us and when I looked back again I had lost Sansoni. I moved toward the lieutenant to tell him the scientist had escaped, but he shushed me before I could speak. He pointed to Sansoni. He was down on his hands and knees in the dark. Collins and 
I both halted. Then Sansoni suddenly began to croon strange songs in a high soft voice. I knew they were the thirteenth-century carols of Shobuta.

“' 'Lieutenant,' I whispered.

" 'What is it?' The lieutenant was whispering also.

" 'He's seen the dodo.'

" 'We know that.'

“'He's an ornithologist.'

“' 'We know that.'

" 'Even if he only saw it through field glasses-'

" 'What?'

" "-he'd have made-observations.'

"'Yes. What of it?'

" 'He know its lairs, he knows its habits.'

" 'Yes. We know that.'

“ 'He can do its signals.' I shuddered.

" 'Will you be quiet?'

“ 'He'll find it.'

"The lieutenant shook me off. He moved toward Sansoni. Quietly he went down on his hands and knees. In the dark I lost them both. I was not alone though. The Japanese had caught up with us. I could hear their leathery movements all around me. I sank down on my hands and knees. There we were, Americans and Japanese, crawling around in those queer, dry grasses, soundless as Indians. We could have been cats and birds observing some petty detail of a neutrality mechanical as the fingers crossed time-out of children in a murderous game. There is something awful in spurious peace-in white flags, sanctuary, the 'foreign soil' of embassies. I hate arrangements.

"A match flared suddenly in the darkness, its light rolling across the face of the Japanese on the plane with me, the one who'd helped me with my seat. He grinned and blew out the match. Someone laughed. It sounded like Sansoni.

"'Lieutenant?'

“Perhaps they've already killed him, I thought. I stopped where I was and waited till I could no longer hear the soldiers. I crawled to a tree and leaned against it. The bark was thorny and I moved away, back into the leathery low tide of the grass. I rooted about in it for awhile and suddenly came on something soft, a comfortable spongy ring. I lay my head in its center and closed my eyes, and something warm and featherish brushed my face. I didn't have to see it to know it was the dodo bird. I'd invaded its nest. I felt the bird's body stiffen and move backwards. No, stay, I thought, I'm no hog. Then I grabbed its legs and pulled it to me for a hostage.

"In the dark, directionless, I traveled with it many hours. Several times we passed Japanese, but I had hidden it under my shirt, next to my skin, and made, on the ground on my hands and knees, the exaggerated, exploratory pats of one searching for something under a bed. Over the old rough ground we went, a trade route of the extinct, and I thought of dinosaurs and mammoths and the sabre-toothed tiger, and here was I, Dick Gibson, with that other loser, the dodo. Back, I thought, cursing it, back to history, you. And even though I still hadn't gotten a good look at it I could tell from its shape against my skin what 
it was-and from its silence and useless, resisting wing that whipped at me percussive as a terrorized heart. It scratched me. It pissed on me and shit on me and I gagged, and my own vomit covered the bird's stench and saved me from the Japanese. When the sun comes up I will be killed, I thought.

"Then I heard Sansoni's voice. He was perhaps a hundred yards off, but I could hear him talking to Collins, or to me, perhaps, if Collins was already dead.

"'It's useless in the dark,' he was saying. 'Most likely it's asleep. We shall have to wait and look for its nest in the morning. I'll tell them.' He spoke briefly in Japanese, and I heard the men laugh. For all I knew he had told them to kill us. I froze where I was, and forgetting that the bird was mute, I reached inside my shirt and grabbed its beak and held it shut. This only made it thrash the more. I think it bit me. Quietly as I could I removed the bird and set it down on the ground. 'Go,' I whispered to it, and shoved it away. I heard the soldiers taking off their packs, and after awhile their heavy breathing.

"The bird wouldn't leave me. I don't know why. So I sat with it in my lap and waited till morning, and all that night I could think of no plan.

"Just after dawn I heard the others getting up and Sansoni organizing them, telling them what to look for. There was a heavy mist. I couldn't see them very well. I saw where the bird had bit me and thought of the dodo's extinct germs working in my blood.

"I stood up. The bird was in my arms.

“' The search is over,' I said. 'I have it. It's mine.'

"A Japanese came out of the fog and smiled and called out to the others. I could hear the word go round the forest. They were maybe two hundred feet from me when Collins pushed through the vanguard. Though I had thought him dead I was not surprised to see him. I was very detached.

“'You found it?' he yelled.

"I held it up.

“'They'll take it. Run. Go on. Get going.'

“'They can't shoot. You said so yourself.'

“'Run!'

"The Japanese were coming towards me. They were twenty-five yards off now.

" 'They're going to take the bird," Collins screamed.

"They were fifty feet off.

“' 'Kill it,' he yelled.

" 'What?"

“' Kill the damn thing. They mustn't have it. Kill it!'

" "What good will that do?"

“'That's an order, Sergeant.' Collins was pointing his pistol at me. 'Kill it, or I'll kill you.'

" 'It bit me,' I said lazily.

“'Kill it.' The Japanese stopped where they were. They were staring at Collins and at me. 'Kill it, god damn you. Kill it!'

“' 'I have no gun.' I had yelled this. The loudness of my voice surprised me.

"Sansoni had begun to plead with me. 'If you let it live we'll treat you as a prisoner. My word. Geneva conventions. My word on that, Sergeant.' 
“' Kill it,' Collins screamed. 'Kill it, or I promise I'll shoot you.' He reached into his pocket and pulled out something black. He threw it toward me. He was very excited. 'Here,' he shouted. 'Pick up the knife. Wring its neck. Cut its throat.'

“'Please, my dear Sergeant,' Sansoni said. 'We'll let you off. We'll allow you both to return to the garrison. All we want is the dodo.'

" 'I'll count to three, Sergeant,' Collins yelled. 'I'll shoot you. I swear it.'

"The knife had landed at my feet. 'One-' Collins shouted. '-two-'

"I bent down and picked up the knife. I turned it in my hand and examined it. I opened it up.

“'Good,' Collins said. 'They mustn't get their hands on it. Remember what we're fighting for.'

“ 'It's only a bird. Everybody. It's only a bird.'

" 'Kill it!'

"I took the knife and slit its throat. I heard them gasp. It was as if I'd pressed the blade to their own throats.

" 'Ah,' Collins sighed.

"I looked down. Its blood was all over me. Then the Japanese were weeping. Holding the bird against my breast, I started walking toward them. 'It's only a bird,' I said. 'Don't you see? It's just a bird.'

"Then the bird was in the air! They fell away from me. Collins was shrieking. They all were. The bird was in the air and the soldiers screamed. Some tried not to look at me but couldn't turn away their heads. The bird came down against my breast and then rose again-higher this time. And then, falling again, it rose a third time. The Japanese were keening with grief and ecstasy. I moved toward them and they hid from me.

“' 'It's the miracle,' Collins said. 'Oh my God, it's the miracle! I didn't want them to have it. I didn't want them to have their symbol. I never thought . . . Oh Jesus, it's the miracle.'

"Now the bird fell, sunk. I reached out my arms and it settled against my breast for the last time. I carried it to its nest and placed it there. When I turned I saw that the Japanese had lined up on two sides, making a sort of aisle in the forest. I walked through them. Collins fell in beside me. He was crying. The soldiers threw down their weapons. I could hear them murmuring. Rosichicho, they were saying. Invincible, I was invincible. When we passed them I heard a sudden burst of machine gun fire. It was the garrison. They charged into the forest and killed them all-every last Japanese. They have been clearing them out on the other islands, too. Casualties are enormous. On the British side as well. I, of course, am rosichicho.

“Oh. By now I think I've pieced together what's happened here. Why Collins and I were assigned to Mauritius. It was the equipment, wasn't it? It was a test of the equipment. Am I getting warm? You wanted to check its range, and you picked a place where not much was happening in the event these broadcasts were intercepted. They were meant to be meaningless. It was our presence on the plane from Lisbon that attracted the enemy. They sent men to check up on us. That's when they discovered the dodo. And sent for the ornithologist. Then they sent out more men because they figured we knew about the bird, too. 
Then we built up our forces to match theirs. But it was all meant to be meaningless. But that's very hard. You know? Meaning is everywhere, Mauritius as well.

"Collins is dead. Everyone is. 'Dead as a dodo.' We have that expression. I, of course, am rosichicho.

"Only don't bet on it. I tossed the bird. I flung him up myself. With my wrists. Everything with my wrists. Like someone at the free-throw line taking a foul shot." 